DOI https://doi.org/10.30525/978-9934-26-038-4-15

\title{
ОСОБЛИВОСТІ МІКРОБІОЦЕНОЗУ \\ СТАТЕВИХ ОРГАНІВ ТА МІОМАТОЗНИХ ВУЗЛІВ У ЖІНОК РЕПРОДУКТИВНОГО ВІКУ, ХВОРИХ ЛЕЙОМІОМОЮ МАТКИ
}

\author{
Запорожченко М. Б. \\ доктор медичних наук,
}

професор кафедри акушерства та гінекології

Одеський національний медичний університет

Парубіна Д. Ю.

кандидат медичних наук, кафедра акушерства та гінекології

Одеський начіональний медичний університет

\section{Сидоренко А. В.}

асистент кафедри акушерства та гінекології

Одеський наиіональний медичний університет

\author{
Булгар А. В. \\ лікар акушер-гінеколог \\ КНП «Міська клінічна лікарня № 11» Одеської міської ради \\ м. Одеса, Україна
}

Вступ. Своєчасна оцінка мікробіоценозу статевих органів жінки має практичне значення для профілактики виникнення та прогресування дисбіотичних процесів, інфекційних захворювань статевих органів та всього організму $[3,4]$. Визнано, що інфекції генітального тракту являються одним із тригерних факторів виникнення пухлинних процесів жіночих статевих органів, зокрема лейоміоми матки $[1,2]$. У цьому аспекті на особливу увагу заслуговує взаємозв'язок між загальним станом організму пацієнтки, клінічним перебігом лейоміоми матки та станом мікробіоценозу статевих органів.

Мета дослідження: вивчити особливості мікробіоценозу статевих органів та дослідити тканини міоматозних вузлів на наявність асоційованої мікробної флори в жінок репродуктивного віку, хворих лейоміомою матки.

Матеріали та методи дослідження. Відповідно до завдань роботи обстежено 216 жінок репродуктивного віку, хворих лейоміомою матки. 
У залежності від клінічного перебігу лейоміоми матки жінки були розподілені на групи 3 клінічно безсимптомним (група IIA, $\mathrm{n}=108$ ) та клінічно симптомним (група ІІБ, $\mathrm{n}=108$ ) перебігом лейоміоми матки.

Обстеження проводили за загальновизнаними алгоритмами, дотримувались відповідних наказів МО3 України. Проводили бактеріологічне, бактеріоскопічне, ПЛР дослідження матеріалу із піхви, цервікального каналу. Для оцінки мікробіоценозу піхви використовували класифікацію Є.Ф. Кіра (нормоценоз, проміжний тип мазка, дисбіоз, вагініт).

Проведено дослідження на наявність асоційованої інфекційної флори в тканинах міоматозних вузлів матки. У жінок з безсимптомним перебігом (група IIA) оперативне втручання виконано в об'ємі консервативної міомектомії та в жінок з симптомним перебігом (група ІІБ) радикальне хірургічне лікування (гістеректомія з матковими трубами).

Інтраопераційно набирали матеріал з міоматозних вузлів для бактеріологічного дослідження. При гістоморфологічному дослідженні вивчали ознаки запалення: альтерація, ексудація, інтерстиціальний набряк тощо. Міоматозні вузли з підтвердженими ознаками запалення додатково досліджували методом ПЛР та визначали ДНК Chlamydia trachomatis, ДНК Cytomegalovirus, ДНК Mycoplasma hominis, ДНК Mycoplasma genitalium, ДНК Virus Herpes Simplex I, II тощо.

Дослідження виконували в тканинах кожного вузла окремо та співставляли з результатами урогенітального тракту.

Результати дослідження та їх обговорення. Проведене дослідження показало, що стан біоценозу «нормоценоз» виявлено у 8 (7,4 \%) жінок групи IIA, у групі ІІБ хворих 3 «нормоценозом» виявлено не було. У жінок з симптомним перебігом лейоміоми матки (група ІІБ) переважав «проміжний тип» біоценозу піхви - у 54 (50 \%) та «вагініт» - у 15 (13,9 \%) у порівнянні 3 хворими з безсимптомним перебігом лейоміоми матки (група IIA): «дисбіоз» у 46 (42,6 \%), «вагініт» - у 7 (6,5 \%) хворих.

Частота виявлення домінуючих інфекцій у піхвовому вмісті жінок репродуктивного віку, хворих лейоміомою матки, переважала в групі 3 симптомним перебігом: Virus Herpes Simplex 30,6 \% у групі IIA та $32,4 \%$ у групі ІІБ, Cytomegalovirus $27,8 \%$ та $28,7 \%$ відповідно, Chlamydia trachomatis - $25 \%$ та 26,9\% відповідно.

Частота виявлення домінуючих інфекцій у цервікальному каналі обслідуваних жінок також переважала в групі з симптомним перебігом лейоміоми матки. Virus Herpes Simplex у групі IIA - 37 (34,3 \%), у групі ІІБ 41 (38,0 \%), Chlamydia trachomatis 35 (32,4 \%) та 40 (37,0 \%) відпо- 
відно. Лише частота виявлення Cytomegalovirus перевищувала в групі IIA - 36 (33,3 \%) у порівнянні з групою ІІБ - 35 (32,4\%).

При бактеріологічному дослідженні міоматозних вузлів визначалася умовно-патогенна та патогенна флора у високих діагностичних титрах, зокрема: Streptococcus, Staphylococcus, Bacteroides spp., Peptococcus spp. тощо та методом ПЛР визначалися переважно ДНК Chlamydia trachomatis, ДНК Ureaplasma urealyticum та ДНК Cytomegalovirus. Частота виявлення домінуючої інфекційної флори переважала в жінок 3 симптомним перебігом лейоміоми матки: 37,1 \% у групі ІІБ та 31,4 \% у групі IIA, що в 1,4 рази більше та свідчить про роль інфекції в розвитку лейоміоми матки, особливо симптомного типу.

Установлена достовірна різниця між частотою визначення домінуючої мікрофлори методом ПЛР у тканинах міоматозних вузлів та урогенітальному тракті: Mycoplasma hominis у тканинах міоматозних вузлів вища на 30,0 \% порівняно з показниками піхвового вмісту та на 26,0 \% - цервікального каналу, Ureaplasma urealyticum - відповідно на $30,0 \%$ та 26,7 \%, Chlamydia trachomatis -відповідно на $13,4 \%$ та 6,7 \%. Частота Virus Herpes Simplex у міоматозних вузлах однакова з показником у піхвовому вмісті та менша на 6,7 \% по відношенню до цервікального каналу.

При гістоморфологічному дослідженні видалених міоматозних вузлів визначали такі ознаки запалення, як: дистрофія, некробіоз тканин (альтерація); реакція судин у ділянці запалення (ексудація); інтерстиціальний набряк (ексудація); наявність клітин запального ряду (ексудація); наявність процесів проліферації.

Висновки. Результати дослідження свідчать про доцільність визначення біоценозу статевих органів, проведення скринінгового виявлення інфекцій, що передаються статевим шляхом, у жінок репродуктивного віку, хворих лейоміомою матки, у динаміці спостереження. У свою чергу, до алгоритму обстеження хворих з інфекціями, що передаються статевим шляхом, доцільно додати скринінгове виявлення лейоміоми матки.

Такий підхід пояснюємо можливою наявністю інфекційних факторів у тканинах одного або декількох міоматозних вузлів. Наявність ознак запалення при гістоморфологічному дослідженні та концентрації інфекційних агентів у видалених тканинах міоматозних вузлів не виключає їх роль у патогенезі лейоміоми матки, «хибному» рості міоматозних вузлів.

Таким чином, своєчасна корекція мікробіоценозу статевих органів може бути одним із етапів патогенетично обгрунтованої профілактики 
лейоміоми матки шляхом запобіганню дії тригерних чинників як виникнення лейоміоми матки, так і переходу росту пухлини з простого типу в проліферативний [1].

\section{Література:}

1. Запорожченко М.Б., Парубіна Д.Ю., Сидоренко А.В. Спосіб лікування порушень біоценозу статевих шляхів у жінок репродуктивного віку, хворих на лейоміому матки. Збірник наукових праиьь співробітників НМАПО імені П.Л. Шупика. Вип. 34. Київ, 2019. С. 14-24.

2. Кудрина Е.А., Бабурин Д.В. Миома матки: современные аспекты патогенеза и лечения (клиническая лекция). Архив акушерства и гинекологии им. В.Ф. Снегирева. 2016. № 3 (1). С. 4-10

3. Рищук С.В., Пунченко О.Е., Малышева А.А. Эндогенная микробиота влагалища и ее регуляция. Бюллетень Оренбургского научного иентра УрО РАН (электронный журнал. 2013. № 4.31 с.

4. C. Neut, F. Verrier, H.J. Nelis, T. Coenye. Topical Treatment of Infectionus Vaginitis: Effects of Antibiotic, Antifungal, and Antiseptic Drags on the Growth of Normal Vaginal Lactobacillus Strains. Open Journal of Obstetrics and Gynicology. 2015. № 5. P. 173-180. 